\title{
PENINGKATAN KUALITAS PROSES PEMBELAJARAN KELAS V DI SEKOLAH DASAR NEGERI MELALUI TEKNIK SUPERVISI KEPALA SEKOLAH DAN MANAJEMEN KELAS
}

\author{
Wasilah $^{1}$ \\ ${ }^{1}$ Sekolah Dasar Negeri Singajaya 1, Indramayu,wasilah_56@gmail.com
}

\begin{abstract}
ABSTRAK
Masalah dalam penellitian ini adalah seberapa besar pengruh Supervisi Kepala Sekolah Dan Pengelolaan Kelas Terhadap Kualitas Proses Pembelajaran Kelas V Pada Sekolah Dasar Negeri di UPTD Pendidikan Kecamatan Indramayu Kabupaten Indramayu. Masalah penelitian diteliti melalui pendekatan kuantitatif. Dengan sumber data penelitian adalah guru-guru pada SD Negeri di UPTD Pendidikan Kecamatan Indramayu Kabupaten Indramayu berjumlah 457 orang guru. Karena jumlah populasi besar diputuskan untuk diambil sampel 110 orang guru. Data dikumpulkan melalui angket langsung yang dijawab oleh para guru, selanjutnya dianalisis secara statistik dengan teknik analisis regresi ganda menggunakan komputer program SPSS Versi 24.0. Hasil analisis regresi menunjukkan bahwa: (1) Hasil uji t diperoleh $\hat{Y}=29,373+1,149$ X1. Konstanta sebesar 29,373 menyatakan bahwa jika tidak ada kenaikan nilai dari variabel supervisi kepala sekolah (X1) maka kualitas proses pembelajaran adalah 29,373. Koefisien regresi sebesar 1,149 menyatakan bahwa setiap perubahan satu skor atau nilai supervisi kepala sekolah memberikan kenaikan skor sebesar 1,149. (2) Hasil uji t diperoleh $\hat{Y}=47,026+0,308 \mathrm{X}_{2}$ konstanta sebesar 47,026 menyatakan bahwa jika tidak ada kenaikan nilai dari variabel manajemen kelas $\left(\mathrm{X}_{2}\right)$, maka kualitas proses pembelajaran (Y) adalah 47,026. Koefisien regresi 0,308menyatakan bahwa setiap perubahan satu skor nilai manajemen kelas memberikan kenaikan 0,308. (3) Hasil uji hubungan korelasi ganda antara variabel supervisi kepala sekolah $\left(\mathrm{X}_{1}\right)$ dan manajeman kelas $\left(\mathrm{X}_{2}\right)$ secara bersama - sama terhadap kualitas proses pembelajaran (Y) adalah 0,553. Hal ini dapat di lihat dari persamaan regresi $\hat{Y}=29,373+1,149 \mathrm{X}_{1}+0,358 \mathrm{X}_{2}$ sehingga setiap perubahan skor supervisi kepala sekolah dan manajemen kelas sebesar satu satuan dapat mengubah 1,149 dan 0,358 skor kualitas proses pembelajaran pada arah yang sama.
\end{abstract}

\section{Kata kunci: Supervisi Kepala Sekolah, Manajemen Kelas, Kualitas Proses Pembelajaran.}

\section{PENDAHULUAN}

Pendidikan merupakan sesuatu yang sangat signifikan bagi pembentukan karakter sebuah peradaban dan kemajuan. Tanpa pendidikan, sebuah bangsa atau masyarakat tidak akan mendapatkan kemajuannya, sehingga menjadi bangsa atau masyarakat yang kurang atau bahkan tidak beradab. Karena itu, sebuah peradaban akan lahir dari suatu pola pendidikan yang tepat guna dan efektif serta mampu menjawab segala tantangan zaman (Abdullah Munir, 2013: 1)

Pendidikan merupakan investasi jangka panjang dalam membangun sumber daya manusia yang mempunyai nilai strategis bagi kelangsungan peradaban manusia. Oleh 
sebab itu, hampir semua negara menempatkan variabel pendidikan sebagai suatu yang penting dan utama dalam konteks pembangunan bangsa dan negara. Bahkan ada beberapa negara yang menempatkan pendidikan di urutan pertama dalam membangun bangsa.

Dalam kenyataan, guru belum memperoleh haknya untuk dapat memanajemen kelas dan mengajar secara profesional serta efektif, hal ini tercermin dari kondisi saat ini yang mencakup jumlah guru yang kurang sehingga harus bekerja melebihi lingkup tugasnya, kualitasproses pembelajaran yang belum sesuai dengan tuntutan, distribusi yang kurang merata, kesejahtaraan yang amat tidak menunjang, dan pengelolaan yang tidak kondusif.

Sekolah sebagai suatu komunitas pendidikan membutuhkan seorang figure pemimpin yang dapat mendayagunakan semua potensi yang ada dalam sekolah untuk suatu visi dan misi sekolah. Peran kepala sekolah sebagai supervisor sangat membantu didalam kemajuan dan keberhasilan sekolah, baik dalam meningkatkan kinerja guru maupun dalam meningkatkan kualitas proses pembelajaran di sekolah.

Kunci utama keberhasilan pendidikan salah satunya terletak pada kualitas guru. Mengingat peran guru yang besar dalam proses pendidikan, kepala sekolah sebagai atasan langsung dituntut memiliki kapasitas utama sebagai edukator, manajer, administrator, supervisor, leader, inovator, dan motivator. Sementara itu guru memiliki tugas utama, yaitu: membuat program pembelajaran, melaksanakan program pembelajaran, melaksanakan evaluasi, melaksanakan analisis hasil belajar siswa, melaksanakan perbaikan, remedial, dan pengayaan (Aqib, 2012: 82). Tidak semua guru mampu melaksanakan manajemen kelas sebagai tugas utama itu. Banyak faktor yang mempengaruhi. Dua faktor utama adalah kemampuan dan kemauan.

Salah satu bentuk perhatian kepala sekolah yang diberikan kepada para tenaga kependidikan sekolah ialah supervisi. Hal ini menjadi salah satu cara yang dapat diaplikasikan dalam dunia pendidikan. Sebab supervisi memiliki kekuatan yang cukup besar untuk merubah sebuah keadaan seorang. Sebagai supervisor, kepala sekolah diharapkan mampu bertindak sebagai konsultan, sebagai fasilitator yang memahami kebutuhan dari guru dan juga mampu memberi alternatif pemecahannya. Disamping itu, kepala sekolah juga diharap dapat memotivasi guru-guru agar lebih kreatif dan inovatif.Setiap unsur dari pimpinan hendaknya dapat menggerakkan orang lain, baik bawahan atau kolega, sehingga dengan sadar secara bersama-sama bersedia berperilaku untuk mencapai tujuan yang telah ditetapkan (Wahjosumidjo, 2013: 171). 
Dengan kata lain, kegiatan supervisi mampu mewujudkan fungsinya sebagai proses peningkatan kualitaskualitas guru dalam proses pembelajaran melalui kegiatan yang menekankan kepada realisasi diri, pertumbuhan diri, dan pengembangan diri. Pengembangan mencakup aktivitas membantu peningkatan dan pertumbuhan kemampuan, sikap, ketrampilan pengelolaan kelas dan pengetahuan anggota (Satmoko, 2012:22).

Banyak faktor yang dapat mempengaruhi kualitas proses pembelajaran, namun penulis mencoba mengkaji masalah supervisi yang diberikan oleh kepala sekolah dan manajemen kelas oleh guru. Supervisi dalam hal ini adalah mengenai pelaksanaan, pembinaan, dan bimbingan yang diberikan oleh kepala sekolah yang nantinya berdampak kepada kinerja mengajar guru yaitu kualitas pengajaran.

\section{METODE PENELITIAN}

Penelitian ini tergolong jenis penelitian deskriptif kuantitatif. Sedangkan penelitian yang penulis lakukan ini menggunakan metode survei dengan pendekatan korelasional.Teknik pengumpulan data yang digunakan adalah observasi, kuesioner (angket), dan dokumentasi. Variabel yang diteliti menggunakan tiga variabel terdiri dari variabel bebas yaitu supervisi kepala sekolah (X1) dan manajemen kelas (X2), sedangkan variabel berikutnya kualitas proses pembelajaran (Y).

Sebelum digunakan untuk pengambilan data, terlebih dahulu dilakukan uji validitas dan reliabilitas dengan melakukan uji coba instrumen.Uji validitas dalam penelitian ini menggunakan bantuan SPSS for windows release versi 24.0.Untuk mengukur reliabilitas dalam penelitian ini berbantuan SPSS for windows release Versi 24.0 dengan uji statistic Cronbach Alpha.

Populasi dalam penelitian ini adalah seluruh guru SD Negeri yang ada di Kecamatan Indramayu sebanyak 457 guru tersebar di 52 SD Negeri dengan asumsi bahwa seluruh guru sudah dikenai supervisi oleh kepala sekolahnya.Pengambilan sampel dengan teknik proportional random sampling dengan jumlah 52 SD Negeri, jumlah guru 457 secara proporsional atau seimbang dan pengambilannya dilakukan secara random (tidak dipilih namun melalui undian), penulis menetapkan sampel sebesar apabila $25 \%$ dengan perhitungan sebagai berikut: 457 x $25 \%=114,25$ guru. Sehingga diperoleh sampel penelitian sebesar 114 guru.

Metode analisis deskriptif ini digunakan untuk mendeskripsikan masing-masing indikator dalam setiap variabel, yaitu pengaruh supervisi kepala sekolah dan manajeman 
kelas terhadap kualitas proses pembelajaran.Rumus yang digunakan untuk mendeskripsikan nilai variabel adalah sebagai berikut:

$$
\%=\frac{f}{N} X 100 \%
$$

Keterangan:

$$
\begin{aligned}
& \%=\text { Persentase } \\
& \mathrm{f}=\text { Nilai yang diperoleh } \\
& \mathrm{N}=\text { Jumlah total responden (Ali, 2014: 104) }
\end{aligned}
$$

Uji normalitas data menggunakan uji statistic Kolmogrov-Smirnov (K-S) dengan bantuan SPSS for windows relese Versi 24.0. Selanjutnya dilakukan uji linearitas dengan pengujian multikolinieritas dalam penelitian ini berbantuan SPSS for windows relese Versi 24.0, dan pengujian heteroskedastisitas dengan mengamati grafik scatter plot melalui program SPSS for windows relese Versi 24.0. Kemudian dilakukan analisis regresi ganda untuk membuat model matematika antara pengaruh supervise kepala sekolah dan pengelolaan kelas terhadap kualitas proses pembelajaran di kecamatan Indramayu. Pengujian hipotesis dilakukan dengan uji $\mathrm{F}$ atau simultan digunakan untuk membuktikan kebenaran pada hipotesis 1 menggunakan program SPSS for Windows release versi 24.0, uji parsial atau uji t digunakan untuk menguji kebenaran pada hipotesis 2 dan 3. Terakhir adalah dengan menentukan koefisien determinasi dan determinasi parsial.

\section{HASIL DAN PEMBAHASAN}

Dalam menganalisis data dilakukan sesuai dengan prosedur yang telah ditetapkan dalam bab sebelumnya, kemudian dilakukan seleksi data dengan hasil yaitu angket yang disebar seluruhnya 114 dari semua angket yang disebar kepada responden dikembalikan sebanyak 110. Hasil pengolahan data pada variabel supervisi kepala sekolah dengan menggunakan 7 item pertanyaan yang diajukan kepada 110 orang responden dengan total nilai 3299, dengan nilai rata-rata tanggapan responden sebesar 28. Standar deviasi 3,2 dan varian sebesar 10,5. Hasil pengolahan data dapat dilihat bahwa nilai tertinggi 35 dan nilai terendah 20. Penyebaran skor supervisi kepala sekolah menunjukan bahwa 57 responden (51\%) memperoleh skor disekitar nilai rata-ratanya yang bervariasi antara 27 - 30 . Terdapat 15 respoden (14\%) memperoleh skor dibawah rata-rata yang bervariasi antara 20 - 26. Sedangkan sebagian lagi ada di atas rata-rata, yaitu sebanyak 37 responden (34\%). 
Hasil pengolahan data pada variabel pengelolaan kelas dengan menggunakan 15 item pertanyaan yang diajukan kepada 110 orang responden dengan total nilai 3775, dengan nilai rata-rata tanggapan responden sebesar 60,2. Standar deviasi 6,1 dan varian sebesar 37,2. Hasil pengolahan data yaitunilai tertinggi 75 dan nilai terendah 50.Penyebaran skor manajemen kelas sebagaimana diperhatikan pada tabel 4.8 di atas, menunjukan bahwa 6 responden $(5 \%)$ memperoleh skor disekitar nilai rata-ratanya yang bervariasi antara 60 64. Terdapat 7 respoden (7\%) memperoleh skor dibawah rata-rata yang bervariasi antara 50 - 59. Sedangkan sebagian lagi ada di atas rata-rata, yaitu sebanyak 97 responden (88\%).

Hasil pengolahan data pada variabel kualitas proses pembelajaran dengan menggunakan 18 item pertanyaan yang diajukan kepada 110 orang responden dengan total nilai 4513, dengan nilai rata-rata tanggapan responden sebesar 80,8. Standar deviasi 6,3 dan varian sebesar 40,3. Hasil pengolahan data yang didapat bahwa nilai tertinggi 90 dan nilai terendah 61.Penyebaran skor manajemen kelas sebagaimana diperhatikan pada tabel 4.9 di atas, menunjukan bahwa 4 responden (2\%) memperoleh skor disekitar nilai rataratanya yang bervariasi antara $73-84$. Terdapat 0 respoden $(0 \%)$ memperoleh skor dibawah rata-rata yang bervariasi antara 61 - 72. Sedangkan sebagian lagi ada di atas ratarata, yaitu sebanyak 106 responden (96\%).

Berdasarkan hasil perhitungan diperoleh rata-rata varibel $\mathrm{X}_{1}$ sebesar 28 dari skor idealnya. Harga ini pada katagori rendah/lemah. Menurut klasifikasi yang telah ditetapkan dan dapat disimpulkan bahwa supervisi kepala sekolah yang dilaksanakan berada pada taraf rendah/lemah. Dengan demikian jelaslah bahwa hasil penelitian ini menunjukan kecendrungan umum supervisi kepala sekolah yang dilakukan pada SD Negeri di UPTD Pendidikan Kecamatan Indramayu Kabupaten Indramayu berada pada katagori rendah/lemah.

Berdsarkan hasil perhitungan diperoleh rata-rata varibel $\mathrm{X}_{2}$ sebesar 60,2 dari skor idealnya. Harga ini pada katagori kuat/tinggi. Menurut klasifikasi yang telah ditetapkan dan dapat disimpulkan bahwa manajemen kelas yang dilaksanakan berada pada taraf rendah/lemah. Dengan demikian jelaslah bahwa hasil penelitian ini menunjukan kecendrungan umum manajemen kelas yang dilakukan pada SD Negeri di UPTD Pendidikan Kecamatan Indramayu Kabupaten Indramayu berada pada katagori kuat/tinggi.

Berdsarkan hasil perhitungan diperoleh rata-rata varibel $\mathrm{Y}$ sebesar 80,8 dari skor idealnya. Harga ini pada katagori sangat kuat. Menurut klasifikasi yang telah ditetapkan 
dan dapat disimpulkan bahwa manajemen kelas yang dilaksanakan berada pada taraf sangat kuat. Dengan demikian jelaslah bahwa hasil penelitian ini menunjukan kecendrungan umum kualitas proses pembelajaran yang dilakukan pada SD Negeri di UPTD Pendidikan Kecamatan Indramayu Kabupaten Indramayu berada pada katagori kuat/tinggi.

Didapat bahwa hasil pengujian normalitas menggunakan Kolmogorov-Smirnov Test nilai Asymp. Sig.(2-tailed) untuk supervisi kepala sekolah atau $\mathrm{X}_{1}$ sebesar 0.253, nilai Asymp. Sig.(2-tailed) untuk manajeman kelas atau X2 sebesar 0.198, dan nilai Asymp. Sig.(2-tailed) untuk kualitas proses pembelajaran atau Y sebesar 0.126.

Semua nilai Asymp. Sig.(2-tailed) ketiga variabel tersebut lebih dari 0,05 $(>0,05)$ berarti signifikan. Sehingga hasil pengujian diatas memberikan makna bahwa sebaran skor variabel supervisi kepala sekolah (X1), manajeman kelas (X2) dan kualitas proses pembelajaran (Y) berdistribusi normal, maka analisis untuk menguji hipotesis dapat dilakukan.

Besarnya hubungan supervisi kepala sekolah (X1) dengan kualitas proses pembelajaran (Y) yang dihitung dengan pearson correlation adalah 0,133. Hal ini menunjukan adanya hubungan yang positif antara supervisi kepala sekolah dengan kualitas proses pembelajaran. Pengujian hipotesis pertama dalam penelitian ini dapat diketahui bahwa nilai Sig $(0,000<0,05)$ maka hasilnya H0 ditolak dan H1 diterima, artinya terdapat pengaruh positif dan signifikan supervisi kepala sekolah terhadap kualitas proses pembelajaran. Diketahui bahwa $\mathrm{R}$ sebesar 0,238. Hal ini menunjukkan bahwa terjadi hubungan yang kuat antara supervisi kepala sekolah terhadap kualitas proses pembelajaran. Sedangkan nilai $\mathrm{R}$ Square 0,238 menunjukkan koefisien $=\mathrm{r}^{2} \times 100 \%=0,238 \times 100 \%=$ 23,8 \%, artinya variabel $\mathrm{Y}$ dipengaruhi oleh variabel $\mathrm{X}_{1}$ sebesar 23,8 \% dan sisanya sebasar $76,2 \%$ dipengaruhi oleh variabel $\mathrm{X}_{2}$ dan variabel lain yang tidak diteliti dalam penelitian ini.

Berdasarkan hasil perhitungan, besar hubungan manajemen kelas $\left(\mathrm{X}_{2}\right)$ dengan kualitas proses pembelajaran (Y) yang dihitung dengan korelasi adalah 0,235. Hal ini menunjukan adanya hubungan yang positif antara manajemen kelas dengan kualitas proses pembelajaran. Pengujian hipotesis kedua dalam penelitian ini dapat diketahui bahwa nilai Sig $(0,002<0,05)$ maka hasilnya H0 ditolak dan H1 diterima, artinya terdapat pengaruh positif dan signifikan terdapat pengaruh positif dan signifikan manajemen kelas terhadap kualitas proses pembelajaran.Dari yangtelah diketahui bahwa $\mathrm{R}$ sebesar 0,959. Hal ini 
menunjukkan bahwa terjadi hubungan yang kuat antara motivasi terhadap Kualitas Proses Pembelajaran. Sedangkan nilai $R$ Square 0,920; ini berarti koefisien $=\mathrm{r}^{2} \mathrm{x} 100 \%=0,920 \mathrm{x}$ $100 \%=92,0 \%$, artinya variabel $\mathrm{Y}$ dipengaruhi oleh variabel $\mathrm{X}_{2}$ sebesar $92,0 \%$ dan sisanya sebasar $8 \%$ dipengaruhi oleh variabel $X_{1}$ dan variabel lain yang tidak diteliti dalam penelitian ini.

Hasil perhitungan menunjukan persamaan regresi dari hasil perhitungan olah data dengan software SPSS yaitu: $\hat{Y}=29,373+1,149 \mathrm{X}_{1}+0,358 \mathrm{X}_{2}$. Konstanta sebesar 29.373 menyatakan bahwa jika tidak ada kenaikan nilai dari variabel supervisi kepala sekolah $\left(\mathrm{X}_{1}\right)$ dan manajemen kelas $\left(\mathrm{X}_{2}\right)$ maka kualitas proses pembelajaran $(\mathrm{Y})$ adalah 29.373. Koefisien regresi sebesar 1,149 dan 0,358 menyatakan bahwa setiap perubahan satu skor atau nilai supervisi kepala sekolah dan manajemen kelas akan memberikan kenaikan skor 1,149 dan 0,358 unit pada kualitas proses pembelajaran.Pengujian signifikasi untuk perhitungan regresi digunakan uji F pada tabel 4.20 menunjukan bahwa $F_{\text {hitung }}$ sebesar 29,222 dengan taraf signifikasi 0,000 kurang dari taraf nyata 0,05 ( $\alpha=5 \%$ ) dan jika dibandingkan dengan $F_{\text {tabel }}$ dengan kesalahan uji $5 \%$ derajat bebas 1 (dfi) sama dengan 2 dan derajat bebas 2 (df2) sama dengan 107 sebesar 0,174; maka $F_{\text {hitung }}>F_{\text {tabel }}$ $(29,222>0,174)$ berarti persamaan $\hat{Y}=29,373+1,149 \mathrm{X}_{1}+0,358 \mathrm{X}_{2}$ signifikan. Artinya terdapat pengaruh yang signifikan antara supervisi kepala sekolah $\left(\mathrm{X}_{1}\right)$ dan manajemen kelas $\left(\mathrm{X}_{2}\right)$ secara bersama - sama terhadap kualitas proses pembelajaran $(\mathrm{Y})$.

Berdasarkan penjelasan diatas, maka pengujian hipotesis ketiga dalam penelitian ini, hasil akhirnya Ho ditolak dan H1 diterima, artinya terdapat pengaruh positif dan signifikan supervisi kepala sekolah dan manajeman kelas secara bersama - sama terhadap kualitas proses pembelajaran. Sedangkan untuk menyatakan besar kecilnya pengaruh variabel supervisi kepala sekolah $\left(\mathrm{X}_{1}\right)$ dan manajeman kelas $\left(\mathrm{X}_{2}\right)$ secara bersama - sama terhadap kualitas proses pembelajaran (Y) dapat diketahui dari tabel diatas $\mathrm{R}^{2}$ sebesar 0,305 . Ini memberikan arti bahwa pengaruh supervisi kepala sekolah $\left(\mathrm{X}_{1}\right)$ dan manajeman kelas $\left(\mathrm{X}_{2}\right)$ secara bersama - sama terhadap kualitas proses pembelajaran (Y) sebesar 30,5 \% sedangkan sisanya 69,5\% ditentukan oleh faktor yang lain yang tidak diteliti pada penelitian ini. 


\section{PENUTUP}

Kesimpulan yang dapat diambil dari penelitian ini adalah sebagai berikut.

1. Supervisi kepala sekolah terhadap kualitas proses pembelajaran pada SD Negeri di UPTD Pendidikan Kecamatan Indramayu Kabupaten Indramayu, terbukti dari hasil ujit diperoleh $\hat{Y}=29,373+1,149$ X1. Konstanta sebesar 29,373 menyatakan bahwa jika tidak ada kenaikan nilai dari variabel supervisi kepala sekolah (X1) maka kualitas proses pembelajaran adalah 29,373.

2. Manajemen kelas terhadap kualitas proses pembelajaran pada SD Negeri di UPTD Pendidikan Kecamatan Indramayu Kabupaten Indramayu, terbukti dari hasil uji-t diperoleh $\hat{Y}=47,026+0,308 \mathrm{X}_{2}$ konstanta sebesar 47,026 menyatakan bahwa jika tidak ada kenaikan nilai dari variabel manajemen kelas $\left(\mathrm{X}_{2}\right)$, maka kualitas proses pembelajaran (Y) adalah 47,026. Koefisien regresi 0,308menyatakan bahwa setiap perubahan satu skor nilai manajemen kelas memberikan kenaikan 0,308.

3. Supervisi kepala sekolah dan manajemen kelas terhadap kualitas proses pembelajaran kelas V pada SD Negeri di UPTD Pendidikan Kecamatan Indramayu Kabupaten Indramayu, terbukti dari hasil uji hubungan korelasi ganda antara variabel supervisi kepala sekolah $\left(\mathrm{X}_{1}\right)$ dan manajeman kelas $\left(\mathrm{X}_{2}\right)$ secara bersama - sama terhadap kualitas proses pembelajaran $(\mathrm{Y})$ adalah 0,553. Hal ini dapat di lihat dari persamaan regresi $\hat{Y}=29,373+1,149 \mathrm{X}_{1}+0,358 \mathrm{X}_{2}$ sehingga setiap perubahan skor supervisi kepala sekolah dan manajemen kelas sebesar satu satuan dapat mengubah 1,149 dan 0,358 skor kualitas proses pembelajaran pada arah yang sama.

Saran yang dapat diberikan dari penelitian ini adalah sebagai berikut:

1. Pihak kepala sekolah dianjurkan mempertahankan dan senantiasa melestarikan budaya menghargai, menghormati dan mengawasi kinerja paraguru dengan tetap mengadakan supervisi pengajaran/pendidikan dan lebih memperhatikan teknik-teknik evaluasi pembelajaran yang tepat sehingga dapat digunakan guru dalam pembelajaran karena hal ini mampu meningkatkan rasa tanggungjawab guru sebagai pengajar.

2. Guru-guru hendaknya tetap memotivasi dirinya dalam pelaksanaan tugas dan tanggungjawabnya menjadi lebih efektif dengan lebih meningkatkan dirinya dan ulet dalam bekerja. Selain itu, usaha untuk lebih percaya pada diri sendiri dan tidak mudah putus asa jika menemui kesulitan sehingga mampu memecahkan masalah, dipandang sebagai salah satu cara untuk meningkatkan motivasi dalam bekerja. 
3. Para guru dianjurkan sesering mungkin membaca, menerapkan dan membuat penelitan pendidikan yang berkaitan dengan pengajaran. Hal ini akan bermanfaat untuk menemukan bagaimana cara-cara pengelolaan kelas yang baik seperti, perencanaan pembelajaran, kesiapan kelas sebelum pengajaran dimulai serta menumbuhkan terjalinnya interaksi belajar mengajar yang kondusif antar siswa dengan guru.

\section{UCAPAN TERIMAKASIH}

Pada kesempatan ini juga kami ucapkan terima kasih yang setulus-tulusnya kepada semua pihak yang telah membantu penulisan karya ilmiah ini.

\section{DAFTAR PUSTAKA}

Munir, Abdullah. (2013). Pendidikan Karakter. Yogyakarta: Pedagogie.

Satmoko. (2012). Prinsip-Prinsip dan Vektor-Vektor Percepatan proses Internalisasi Nilai Kewirausahaan. Disertasi. Bandung: PPs IKIP Bandung.

Wahjosumidjo. (2013). Kepemimpinan Kepala Seklah - Tinjauan Teoritik dan Permaasalahannya. Jakarta: Rajawali Pers.

Aqib, Zainal. (2012). Pendidikan Karakter di Sekolah Membangun Karakter Kepribadian Anak. Bandung: Yrama Widya. 